\section{TINJAUAN YURIDIS TERHADAP PERUSAHAAN JASA PENILAI (APPRAISAL COMPANY) [Studi Pada Kantor Jasa Penilai Publik Henricus Judi Adrianto] $^{1}$ \\ Oleh: Pricilia Dwi Anggreni Putri²}

\begin{abstract}
ABSTRAK
Tujuan dilakukannya penelitian ini adalah untuk
\end{abstract} mengetahui bagaimana kedudukan hukum Perusahaan Jasa Penilai dan bagaimana perlindungan hukum bagi perusahaan jasa penilai, pemakai jasa, dan pihak ketiga dalam pelaksanaan perjanjian penilaian aktiva tetap serta bagaimana tanggung jawab perusahaan jasa penilai dalam melaksanakan penilaian aktiva tetap. Dengan menggunakan metode penelitian yuridis normatif, disimpulkan: 1 . Kegiatan-kegiatan perusahaan jasa penilai di Indonesia relatif masih baru dan belum begitu memasyarakat, namun secara hukum eksistensi atau keberadaannya telah diakui sebagai badan usaha yang berbentuk badan hukum. 2. Dalam perlindungan hukum terhadap perbuatan yang melanggar aturan-aturan hukum yang ditanggung oleh sebuah perusahaan jasa penilai kepada pemakai jasa dan pihak ketiga didasarkan atas suatu tanggung jawab perusahaan penilai yang terdapat dalam Kode Etik Penilaian Indonesia (KEPI) dan Pasal 19 Undang - Undang Perlindungan Konsumen. 3. Tanggung jawab perusahaan jasa penilai dalam melakukan penilaian aktiva tetap terdapat dalam syarat-syarat pembatasan penilaian yang terdapat dalam laporan hasil penilalan dengan memperhatikan tanggung jawab penilai dan kode etik gabungan perusahaan penilai. Selain itu isi perjanjian penilaian aktiva tetap juga menjadi dasar tanggung jawab perusahaan jasa penilai. Segala tindakan dan hasil penilaian perusahaan jasa penilai haruslah dipertanggung-jawabkan secara hukum seperti tanggung jawab perdata dan tanggung jawab administrasi. Tanggung jawab perusahaan jasa penilai selama ini masih dituruti oleh perusahaan jasa penilai dalam melakukan penilaian aktiva tetap.

Kata kunci: Tinjauan Yuridis, Perusahaan, Jasa Penilai

1 Artikel Skripsi. Dosen Pembimbing: Doortje Durin Turangan, S.H., M.H; Cevonie M. Ngantung, S.H., M.H

2 Mahasiswa pada Fakultas Hukum Unsrat, NIM. 16071101613

\section{PENDAHULUAN}

\section{A. Latar Belakang Penelitian}

Perusahaan atau perseorangan yang menggunakan jasa penilai properti adalah perusahaan atau perseorangan yang meminjam kredit bank untuk mengembangkan usahanya dan perusahaan-perusahaan yang bermasalah, yaitu perusahaan yang memiliki kredit macet, perusahaan yang pailit dan lain sebagainya. Bagi pihak perbankan, penilaian aset memang sangat penting untuk menentukan berapa besar pinjaman uang (kredit) yang dapat diberikan, sedangkan bagi perusahaanperusahaan yang bermasalah, penilaian aset yang masih ada penting pula dilakukan untuk penilaian lelang. Disamping itu, ada pihak pemerintah yang menggunakan perusahaan jasa penilai publik yaitu dalam hal pengadaan tanah untuk kepentingan umum dan inventarisasi aset-aset daerah yang digunakan untuk laporan keuangan.

Pada tahun 2000 sampai dengan sekarang ini, jasa-jasa penilai berkembang dengan pesat seiring dengan pertumbuhan-pertumbuhan sektor properti dan pengadaan-pengadaan infrastruktur kota yang semakin modern. Perusahaan jasa penilai (appraisal company) merupakan sebuah perusahaan yang sifatnya independen. Perusahaan jasa penilai (appraisal company) yang dulunya hanya menilai agunan kredit kemudian memperluas kegiatan-kegiatan usaha seperti yang tercantum dalam Pasal 2 Keputusan Menteri Perindustrian dan Perdagangan Nomor 594/MPP/Kep/VII/2002 tentang Ketentuan Perizinan Usaha Jasa Penilaian.

Profesi penilai memberikan jasa profesional dalam menentukan nilai wajar dari harta milik perusahaan (aktiva). Penilai menentukan seberapa besar nilai kekayaan emiten dan hal ini akan berpengaruh pada penentuan harga saham atau obligasi yang akan dikeluarkan emiten dalam rencana go public. ${ }^{3}$ Sebelum berkembangnya lembaga penilai, penilaian dilakukan oleh lembaga pajak dengan melakukan perhitungan indeks. Namun karena tujuan emisi lebih meminta kelengkapan penilaian kembali aktiva perusahaan yang akan go public tersebut daripada sekedar

\footnotetext{
3 Swawidji Widoatmodjo, Jurus Jitu Go Public, cet. 2, (Jakarta: PT. Elex Media Komputindo), 2004, hal. 79
} 
perhitungan pajak, maka kemudian penilai selalu dituntut untuk menjaga kepentingan pemegang saham publik dan lembaga penilaian dirasa lebih dibutuhkan dalam hal ini. ${ }^{4}$

Dalam perkembangan ekonomi dewasa ini, penilaian aset-aset properti dalam hal ini tanah dan bangunan lebih banyak dilakukan dibandingkan dengan penilaian-penilaian harta kekayaan lainnya. Penilaian aset tanah dan bangunan sebagai aset yang berwujud digunakan sebagai dasar untuk menilai harga pasar dari agunan kredit atau memberi pendapat atas harga dasar aset tersebut untuk dijual kepada pihak lain.

Metode penilaian atas tanah dan bangunan menggunakan metode-metode pendekatan data pasar, metode pendekatan kalkulasi biaya penyusutan, dan metode kapitalisasi pendapatan. Metode pendekatan data pasar atas tanah dan bangunan dilakukan dengan cara mengambilnya dan Nilai Jual Objek Pasar yang merupakan tax base dari pajak bumi dan bangunan. Selain itu, penilaian aset tanah dan bangunan juga memperhatikan semua keterangan, faktor-faktor, kapasitas lokasi, lingkungan dan pemanfaatan tertinggi dan terbaik dari tanah dan aset di atasnya yang dikuasai secara fisik oleh perusahaan.

Penilaian-penilaian yang dilakukan secara objektif tanpa ada maksud dan tujuan yang negatif inilah yang harus dilakukan oleh perusahaan jasa penilai agar hasilnya bisa diterima pemakai jasa dan pihak ketiga. Sebagai badan hukum, perusahaan jasa penilai mempunyai tanggung jawab hukum atas hasil penilaian yang dilakukan oleh penilai yang ditunjuknya baik kepada kliennya maupun kepada pihak ketiga yang bersangkutan yang akan memberikan perlindungan hukum atas atas para pihak yang melakukan perjanjian tersebut hal ini sesuai dengan peraturan hukum yang berlaku. ${ }^{5}$

Penilaian-penilaian yang objektif juga merupakan salah satu faktor yang harus diperhatikan dalam rangka menciptakan jaminan dan perlindungan hukum yang memadai bagi investor. Setiap investor dalam

\footnotetext{
4 DR. Sumantoro, Pengantar Tentang Pasar Modal di Indonesia, cet. 1, (Jakarta: Ghalia Indonesia), 1990, hal. 104

5 Johanes Ibrahim, Hukum Bisnis Dalam Persepsi Manusia Modern, (Jakarta: Refika Aditama), 2003, hlm 5
}

rencananya berinvestasi harus mendapatkan kebenaran informasi yang diterbitkan hingga kecepatan, ketepatan, keakuratan, dan kelengkapan informasi yang diterbitkan baik oleh emiten maupun pihak-pihak yang terlibat dalam pasar modal ${ }^{6}$, dalam hal ini khususnya profesi penilai.

\section{B. Perumusan Masalah}

1. Bagaimanakah kedudukan hukum Perusahaan Jasa Penilai?

2. Bagaimanakah perlindungan hukum bagi perusahaan jasa penilai, pemakai jasa, dan pihak ketiga dalam pelaksanaan perjanjian penilaian aktiva tetap?

3. Bagaimanakah tanggung jawab perusahaan jasa penilai dalam melaksanakan penilaian aktiva tetap?

\section{Metode Penulisan}

Metode penulisan yang digunakan dalam penulisan karya ilmiah ini adalah pendekatan yuridis sosiologis. Sumber data yang digunakan dalam penelitian ini meliputi data sekunder dan primer. Data sekunder terdiri dari bahan hukum primer dan hukum sekunder serta menggunakan bahan hukum tersier, data studi pustaka dan literatur dan dokumen dari internet. Data sekunder dari bahan hukum primer yaitu dari perundang-undangan yang berlaku dan mengikat mengenai peraturan hukum di Indonesia. Sedangkan bahan hukum sekunder yaitu bahan hukum yang memberikan penjelasan mengenai bahan hukum primer, sedangkan bahan hukum tersier yaitu bahan hukum yang memberikan petunjuk maupun penjelasan bahan baku hukum primer dan sekunder.

Metode pengumpulan data menggunakan kumpulan dari setudi kepustakaan, obeservasi lapangan serta wawancara bebas terpimpin. Pengumpulan data dilakukan dengan melakukan wawancara terlebih dahulu dengan Henricus Judi Adrianto selaku Director, pemilik Perusahaan Jasa Penilai, yaitu Kantor Jasa Penilai Publik Henricus Judi Adrianto, melakukan telah mendalam mengenai perjanjian antara kedua belah pihak.

Adapun penelitian yang dilakukan oleh Penulis ialah guna membahas tinjauan yuridis

6 Ibid., hal. 151 
terhadap perusahaan jasa penilai dalam melaksanakan suatu penilaian aktiva tetap. Dalam melakukan penelitian ini, alat yang digunakan dalam pengumpulan data adalah studi kepustakaan (library research), yaitu pengumpulan data yang dilakukan melalui data tertulis. $^{7}$

Setelah memperoleh semua informasi dan penjelasan yang diperlukan barulah Penulis dapat mengambil kesimpulan. Kesimpulankesimpulan ini digunakan guna menjawab pokok-pokok permasalahan dalam penulisan dan juga dalam memberikan saran-saran yang mungkin berguna terkait dengan permasalahan tanggung jawab profesi penilai.

\section{PEMBAHASAN}

\section{A. Kedudukan Hukum Perusahaan Jasa Penilai}

Kegiatan perusahaan jasa penilai di Indonesia relatif masih baru dan belum begitu memasyarakat, namun secara hukum eksistensi atau keberadaannya telah diakui sebagai badan usaha yang berbentuk badan hukum dalam hal ini Perseroan Terbatas yang diatur dalam Undang - Undang Nomor 1 Tahun 1995. Kalau dilihat dari prosedur administrasi, perizinannya sama dengan semua bentuk badan usaha lainnya sebagaimana telah diatur dengan Surat Keputusan Menteri Perdagangan Nomor 161/KP/VI/1997 jo Surat Keputusan Menteri Keuangan Nomor 57/KMK.017/1996, hanya saja bentuk usaha ini ada kekhususannya yaitu sebagai jasa penilai. Untuk itu secara hukum Perusahaan Jasa Penilai memiliki hak dan kewajiban yang sama dengan subjek hukum lainnya serta dapat melakukan kegiatannya sesuai dengan izin usahanya.

Profesi penilai di Indonesia merupakan salah satu profesi di bidang jasa yang berada di bawah naungan Pusat Pembinaan Akuntan dan Jasa Penilai Sekretaris Jenderal Kementerian Keuangan. ${ }^{8}$ Pada tahun 1992 terjadi perkembangan yang cukup penting dalam fungsi kelembagaan pemerintah yang menyangkut perkembangan profesi penilai, dimana dengan Keputusan Presiden Nomor 35 tahun 1992 dibentuk Direktorat Jenderal

\footnotetext{
7 Soerjono Soekanto, Pengantar Penelitian Hukum, (Jakarta: UI Press, 1986), hal 21

8 Pusat Pembinaan Akuntansi Dan Jasa Penilai, Sekretaris Jenderal Kementerian Keuangan, Tugas Dan Fungsi Pembinaan Akuntan dan Jasa Penilai.
}

Lembaga Keuangan yang salah satu organnya adalah Direktorat Pembinaan Akuntan dan Jasa Penilai.

Untuk pertama kalinya secara tegas suatu instansi pemerintahan ditugaskan untuk melaksanakan fungsi dan tugas dari lembaga tersebut, lebih lanjut diperinci dalam Keputusan Menteri Keuangan Republik Indonesia Nomor 1254/KMK.01/1992 tanggal 15 Desember 1992.

Peraturan pertama yang khusus mengatur mengenai jasa penilaian dan masih diberlakukan hingga saat ini adalah Surat Keputusan Menteri Perdagangan Republik Indonesia Nomor 161/KP/VI/1977 Tanggal 17 Juni 1977 Tentang Ketentuan Perijinan Usaha Penilai yang antara lain mengatur tentang jasa penilaian barang yang berwujud maupun tidak berwujud, penilaian proyek, penilaian terhadap kelayakan teknis, manajemen harta benda, properti agen dan studi kelayakan.

Pada tahun 1996, pemerintah mengeluarkan Keputusan Menteri Keuangan Republik Indonesia Nomor 57/KMK.017/1996 Tentang Jasa Penilai sebagai tindak lanjut dari upaya pembinaan dan pengembangan profesi jasa penilai serta sebagai perlindungan kepada profesi dan pemakai jasa penilai ini. Dalam keputusan ini diatur mengenai pendirian usaha jasa penilai dan bentuk usaha jasa penilai serta adanya kewajiban profesional penilai dan usaha jasa penilai untuk mendapatkan izin dari menteri keuangan setelah memenuhi persyaratan untuk menjalankan kegiatan penilaian.

Pada tahun 2004, terbit Keputusan Menteri Keuangan Republik Indonesia Nomor 406/KMK.06/2004 tentang Usaha Jasa Penilai Berbentuk Perseroan Terbatas. Dalam peraturan ini diberikan aturan-aturan mengenai bentuk usaha jasa penilai berbentuk Perseroan Terbatas dan perizinannya.

Pada tahun 2008 Menteri Keuangan menerbitkan Peraturan Nomor 125/PMK.01/2008 tentang Jasa Penilai Publik. Peraturan ini dibuat dengan tujuan untuk melindungi kepentingan umum terhadap kebutuhan akan jasa penilai publik yang profesional dan independen. Peraturan ini semakin menegaskan eksistensi penilai terutama penilai publik di bidang usaha jasa di indonesia. 
Pada tahun 2010, terbit Peraturan Menteri Keuangan Republik Indonesia Nomor 01/PMK.03/2010 tentang Pencabutan Keputusan Menteri Keuangan Nomor 406/PMK.06/2004 tentang Usaha Jasa Penilai Berbentuk Perseroan Terbatas. Sejak peraturan ini diberlakukan, maka usaha jasa penilai yang berbentuk perseroan terbatas, mengubah bentuk usahanya menjadi Kantor Jasa Penilai Publik. Alasan diterbitkannya peraturan ini adalah karena profesi penilai lebih dianggap sebagai pemberi jasa. Memperhatikan hal tersebut, maka mulai 1 Januari 2010, perusahaan jasa penilai berbentuk Perseroan Terbatas (PT) tidak diperkenankan lagi melakukan kegiatan usaha di bidang jasa penilaian.

Pada tahun 2014, diterbitkan Peraturan Menteri Keuangan Nomor 101/PMK.01/2014 tentang Penilai Publik. Peraturan ini dibentuk dikarenakan profesi ini menyangkut izin perorangannya bukan izin perseroan terbatas.

Pada tahun 2017, menerbitkan Peraturan Menteri Keuangan Republik Indonesia Nomor 56/PMK.01/2017 tentang Perubahan Atas Peraturan Menteri Keuangan Nomor 101/PMK.01/2014 tentang Penilai Publik.

Selain peraturan-peraturan tersebut diatas, peraturan lain yang juga berhubungan dengan profesi penilai dan usaha jasa penilai di Indonesia adalah:

1. Undang - Undang Republik Indonesia Nomor 8 tahun 1995 tentang Pasar Modal;

2. Keputusan Menteri Keuangan Republik Indonesia Nomor 507/KMK.04/1996 tentang Penilaian Kembali Aktiva Tetap Perusahaan;

3. Keputusan Kepala BAPEPAM Nomor Kep.37/PM/1996 tentang Pendaftaran Penilai Yang Melakukan Kegiatan di Pasar Modal;

4. Keputusan Direktur Jenderal Lembaga Keuangan Nomor KEP.3058/LK/1998 tentang Peraturan Pelaksanaan Atas Keputusan Menteri Keuangan Nomor 57/KMK.017/1996;

5. Keputusan Menteri Perindustrian dan Perdagangan Nomor 594/MPP/KEP/VIII/2002 Tentang Ketentuan Perizinan Usaha Jasa Penilai;
6. Peraturan Otoritas Jasa Keuangan Nomor 68/POJK.04/2017 tentang Penilai yang Melakukan Kegiatan di Pasar Modal.

\section{B. Perlindungan Hukum Perusahaan Jasa Penilai, Pemakai Jasa, Pihak Ketiga Dalam Melaksanakan Perjanjian Penilaian Aktiva Tetap}

Dalam melaksanakan perjanjian penilaian aktiva tetap, tiap-tiap pihak yang terikat dalam perjanjian tersebut yang dalam hal ini perusahaan jasa penilai dengan pemakai jasa berkewajiban tunduk pada kesepakatan yang telah dibuat bersama. Perjanjian penilaian aktiva tetap diadakan untuk memberikan jasa bagi pemakai jasa aktiva tetap dengan memperoleh imbalan pembayaran atas jasa yang dilakukan oleh pihak perusahaan jasa penilai. Perjanjian tersebut melahirkan suatu perikatan yang sesuai Pasal 1313 Kitab UndangUndang Hukum Perdata (KUHPerdata) di mana para pihak mengikatkan diri dalam suatu persetujuan dan berkewajiban melakukan prestasi sesuai dengan isi perjanjian yang telah disepakati.

Perjanjian penilaian aktiva tetap termasuk dalam perjanjian tidak bernama, namun dengan mengacu pada Pasal 1319 Kitab Undang - Undang Hukum Perdata (KUHPerdata) maka perjanjian tersebut akan berlaku sesuai dengan ketentuan umum perikatan (Bab Pertama Dan Kedua Buku III Kitab Undang - Undang Hukum Perdata (KUHPerdata)). Perjanjian penilaian aktiva tetap memberikan sejumlah hak dan kewajiban kepada kedua belah pihak, oleh karena itu perjanjian-perjanjian penilaian aktiva tetap masuk dalam kategori perjanjianperjanjian yang bersifat timbal balik dan telah memenuhi persyaratan dalam Pasal 1320 Kitab Undang-Undang Hukum Perdata (KUHPerdata) yaitu dengan adanya kesepakatan untuk saling mengikatkan diri yang di tuangkan dalam perjanjian tertulis maupun tidak tertulis.

Dalam praktik pelaksanaan perjanjian penilaian aktiva tetap, selalu ada saja kemungkinan terjadinya Wanprestasi dan Perbuatan Melanggar Hukum. Wanprestasi dalam perjanjian penilaian aktiva tetap dapat saja terjadi karena salah satu pihak, baik $^{9}$

\footnotetext{
9 Richard Burton Simatupang, Aspek Hukum dalam Bisnis. (Jakarta: Rineka Cipta), 2003, hlm. 29
} 
perusahaan jasa penilai atau pemakai jasa yang tidak memenuhi kewajibannya sesuai dengan perjanjian yang telah di buat atau karena suatu keadaan yang memaksa seperti bencana alam,kerusuhan, dan lain-lain.

Wanprestasi dan pihak perusahaan jasa penilai terjadi apabila melakukan hal-hal yang tersebut di bawah ini:

1) Sama sekali tidak melakukan, penilaian aktiva tetap;

2) Terlambat meyelesaikan laporan hasil penilaian aktiva tetap tepat waktu;

3) Penilaian aktiva tetap bukan dilakuan oleh tenaga ahli yang berkompeten dan peralatan yang diperlukan tidak kurang memadai atau tidak ada sehingga kebenaran dan mutu pekerjaan tidak akurat dan subjektif; dan

4) Tidak bertanggung jawab penuh atas mutu dan kebenaran laporan hasil penilaian;

Dari keempat bentuk wanprestasi tersebut yang kadang terjadi adalah keterlambatan penyelesaian laporan hasil penilaian. Hal ini biasanya diakibatkan oleh sulitnya melakukan pengumpulan data karena kurangnya data atau kesalahan ${ }^{10}$ data yang diberikan oleh pemakai jasa dan waktu yang diberikan oleh perusahaan jasa penilai terkadang sangat singkat. Contohnya seperti pemberian data aktiva tetap berupa bangunan-bangunan tidak jelas adalah hak milik dari pemakai jasa atau hanya di sewa oleh pemakai jasa karena informasi yang diberikan kurang atau salah.

Dalam kasus seperti ini, pihak perusahaan jasa penilai menanggulangi keterlambatan tersebut dengan mengambil langkah kebijakan dengan meminta kelengkapan data-data yang lengkap kepada pemakai jasa untuk melakukan penilaian sebelum melakukan penilaian objekobjek dan aktiva tetap perusahaan yangakan dinilai dan memeriksa kebenaran data-data yang diberikan oleh pemakai jasa. Mengenai waktu yang diberikan untuk melakukan penilaian aktiva tetap yang singkat karena keperluan yang mendesak dari pemakai jasa, perusahaan penilai menanggulanginya dengan usaha memenuhi penyelesaian penilaian sesuai dengan batas waktu yang telah ditentukan.

10 Subekti. R. dan R. Tjin Sudibyo, Kitab undang-undang hukum perdata. (Jakarta: Rineka Cipta), 2001, hlm. 35
Perbuatan melanggar hukum yang dilakukan oleh perusahaan jasa penilai atau penilai yang menyebabkan kerugian kepada pihak pemakai jasa atau pihak ketiga haruslah disesuaikan dengan tanggung jawab perusahaan penilai dan penilai. Pemakai jasa dan pihak ketiga yang merasa dirugikan oleh perusahaan jasa penilai dan penilai haruslah membuktikan kesalahan dari perusahaan jasa penilai atau penilai tersebut adalah perbuatan melawan hukum yang menimbulkan kerugian bagi orang lain dimana antara perbuataan melawan hukum dengan kerugian mempunyai hubungan kausal. Perlindungan hukum terhadap perbuatan melanggar hukum yang ditanggung oleh perusahaan penilai kepada pemakai jasa dan pihak ketiga yang didasarkan atas tanggung jawab perusahaan penilai yang terdapat dalam Kode Etik Penilai Indonesia (KEPI) dan Pasal 19 Undang - Undang Perlindungan Konsumen (UUPK). Penyelesaian terhadap perbuatanperbuatan yang melanggar hukum perusahaan penilaian yang menimbulkan kerugian yaitu dengan mengganti kerugian pemakai jasa dan pihak ketiga.

Bank sebagai pihak ketiga yang mempunyai kepentingan atas hasil penilaian aktiva tetap yang dibuat oleh perusahaan penilai sebagai salah satu syarat bagi calon penerima kredit untuk mendapatkan kredit dan bank mempunyai hak untuk menerima ganti kerugian terhadap perbuatan melanggar hukum yang dilakukan perusahaan penilai atau pemakai jasa. Dalam menindak lanjuti perselisihan yang terjadi dalam perjanjian penilaian aktiva tetap, baik pihak perusahaan jasa penilai, pemakai jasa dan pihak ketiga berusaha agar diselesaikan dengan cara musyawarah. Apabila ternyata berdasarkan musyawarah tetap tidak terjadi kesepakatan, maka para pihak memilih jalur pengadilan. Tetapi selama penulis melakukan penelitian pada tempat penelitian, mereka tidak pernah membawa atau menyelesaikan perselisihan sampai pada jalur pengadilan karena dapat merusak hubungan baik dengan para pelaku usaha lainnya. Hak yang menyewakan adalah :

a. Uang sewa harus dibayar oleh pihak penyewa tepat pada waktunya sesuai dengan perjanjian.

b. Pihak yang menyewakan berhak untuk menuntut ganti rugi kepada pihak 
penyewa apabila barang yang disewakan rusak.

\section{Tanggung Jawab Perusahaan Jasa Penilai Dalam Melaksanakan Penilaian Aktiva Tetap.}

Berdasarkan Kode Etik Penilai Indonesia (KEPI) ada beberapa macam tanggung jawab yang harus dipatuhi, yaitu sebagai berikut :

1) Tanggung Jawab terhadap Integritas Pribadi Penilai. Dalam menjalankan tugas, penilai mempunyai kewajiban untuk memberikan jasa yang sebaikbaiknya, sesuai dengan kemampuan dan keahlian yang disyaratkan dalam Standar Penilaian Indonesia (SPI), dengan menjunjung tinggi integritas, kejujuran dan tidak memihak.

2) Tanggung Jawab terhadap Pemberi Tugas. Tanggung jawab utama penilai terhadap pemberi tugas adalah memberikan penilaian yang lengkap dan teliti tanpa menghiraukan atau memperhatikan keinginan dan instruksiinstruksi atau permintaan pihak pemberi tugas yang sifatnya dapat mempengaruhi kemandirian atau untuk mengubah hasil penilaian yang obyektif dan tidak memihak sebagaimana ditetapkan dalam Standar Penilaian Indonesia (SPI).

3) Tanggung Jawab terhadap Sesama Penilai dan Usaha Jasa Penilai. Setiap penilai tidak dibenarkan melakukan persaingan curang yaitu antara lain menggunakan imbalan jasa yang lebih rendah daripada standar imbalan jasa (fee) minimum yang ditetapkan oleh asosiasi dan atau dengan mempromosikan dirinya sendiri kepada pemberi tugas untuk menggantikan kedudukan atau mengambil alih penugasan penilai lain dengan dalih dan cara apapun. Apabila penilai mengetahui adanya kecenderungan atau indikasi bahwa penilai yang bersangkutan telah melakukan perbuatan sebagaimana disebutkan pada butir 1 dan 2 di atas adalah menjadi kewajiban setiap penilai untuk melaporkan kepada pengurus asosiasi penilai dan atau Dewan Penilai Indonesia, termasuk memberikan buktibukti yang tersedia yang diperlukan dalam usahanya mengupayakan pengusutan terhadap penilai yang bersangkutan.

4) Tanggung Jawab terhadap Masyarakat. Setiap penilai tidak diperbolehkan:

a) Melakukan kolusi dalam rangka mendapatkan penugasan atau pekerjaan penilaian.

b) Melakukan kegiatan - kegiatan promosi terhadap dirinya sendiri yang sifatnya menurunkan derajat profesi penilai.

5) Praktik-praktik yang Tidak Etis. Praktikpraktik yang Tidak Etis adalah praktik tidak etis dari perusahaan penilai untuk mengaitkan perhitungan upah jasanya dengan :

a) Hasil suatu perselisihan mengenai obyek yang dinilai;

b) Jumlah penurunan pajak dalam hal penentuan pajak adalah berdasarkan laporan penelitian; dan

c) Hasil penjualan barang tertentu yang dinilainya.

Perusahaan jasa penilai yang melakukan penilaian aktiva tetap tidak sesuai dengan Standar Penilaian Indonesia, Kode Etik Penilai Indonesia, dan aturan hukum yang berhubungan dengan penilaian aktiva tetap akan mengakibatkan laporan hasil penilaian menjadi subjektif dan tidak akurat. Laporan hasil penilalan yang akurat dan subjektif akan merugikan pemakai jasa dan pihak ketiga dan Perusahaan jasa penilai harus mengganti kerugian akibat kesalahannya.

Dalam melakukan kegiatan usaha jasa penilaian, perusahaan jasa penilai dan penilai bersama-sama bertanggung jawab terhadap mutu dan kebenaran dan laporan hasil penilaian yang dibuat oleh penilai yang ditunjuk oleh perusahaan jasa penilai. Meskipun mempunyai kesamaan dalam tanggung jawab atas mutu dan kebenaran laporan hasil penilaian, tetapi tangung jawab perusahaan jasa penilai mempunyai perbedaan-perbedaan dalam asumsi dan syarat pembatasan penilaian yang menjadi dasar pembatasan tanggung jawab penilai dan perusahaan penilai. Perbedaan tanggung jawab perusahaan penilai dan penilai juga terdapat tanggung jawab moral dan tanggung jawab hukum.

Tanggung jawab perusahaan penilai dapat dilihat dari asumsi dan syarat pembatasan 
penilaian yang menjadi dasar pembatasan tanggung jawab penilai. Seorang penilai yang melanggar asumsi dan syarat-syarat pembatasan penilaian secara otomatis melanggar Kode Etik Penilai Indonesia dan melakukan perbuatan melanggar hukum yang dapat digugat secara pidana dan perdata. Tanggung jawab moral penilai didasarkan atas Kode Etik Penilai Indonesia (KEPI) yang hanya mengikat penilai yang masuk dalam asosiasi Profesi penilai yang bernama Masyarakat Profesi Penilai Indonesia (MAPPI). Kode Etik Penilai Indonesia (KEPI) tidak mempunyai kekuatan-kekuatan hukum yang tetap sehingga apabila seorang penilai melakukan pelanggaran kode etik maka sanksinya hanya berupa denda atau dikeluarkan dari asosiasi. Sedangkan tanggung jawab hukum seorang penilai adalah apabila melakukan perbuatan-perbuatan yang dapat melanggar hukum secara pribadi ditanggung oleh penilai tersebut. Apabila seorang penilai melanggar hukum dalam melakukan penilaian akan berakibat rusaknya citra perusahaan tempat ia bekerja dan dirinya secara pribadi selaku seorang penilai dan dapat dikenakan hukuman pidana berdasarkan Pasal 1378 Kitab Undang - Undang Hukum Pidana (KUHP) mengenai perbuatan curang dan penipuan dan apabila tindakannya tersebut tanpa didasari oleh persetujuan dari pimpinan perusahaan maka penilai tersebut yang menanggung sendiri ganti kerugian yang akibat tindakan-tindakan perbuatan melawan hukumnya.

Isi perjanjian penilaian aktiva tetap yang menetapkan tanggung jawab masing-masing pihak, baik perusahaan penilai atau pemakai jasa haruslah ditepati agar tidak terjadi wanprestasi yang mengakibatkan kerugian bagi salah satu pihak. Sebagai perusahaan jasa penilai yang menunjuk penilai yang berkompeten dalam melakukan penilaian aktiva tetap, PT Berlian Maju Motor dan PT Surya Prima Abadi bertanggung jawab atas laporan hasil penilaian yang dibuat oleh karyawannya (penilai). Kesalahan dalam laporan hasil penilaian yang dibuat oleh penilai yang menyebabkan kerugian pada pemakai jasa atau pihak $^{11}$ ketiga menjadi tanggung jawab

\footnotetext{
11 Jusuf, AL Haryono. Dasar-dasar Akuntansi. (Yogyakarta: Bagian Penerbitan STIE YKPN), 1994, hlm. 25
}

perusahaan jasa penilai untuk mengganti kerugian tersebut. Hal ini sesuai dengan Pasal 1367 Ayat (3) Kitab Undang - Undang Hukum Perdata di mana pimpinan perusahaan jasa penilai yang menunjuk bawahan atau karyawan (penilai). Untuk mewakili urusan-urusan mereka, adalah bertanggung jawab tentang kerugian yang terbit oleh pelayan-pelayannya atau bawahan-bawahan di dalam melakukan pekerjaan.

Tanggung jawab moral perusahaan jasa penilai terbagi atas 4 (empat) macam, yaitu tanggung jawab terhadap integritas perusahaan jasa penilai, pelanggan, masayarakat, dan kepada sesama perusahaan penilai. Menurut wawancara dengan penilai sewaktu melakukan penelitian, tanggung jawab moral perusahaan jasa penilai terdapat dalam kode etik perusahaan jasa penilai yang dibuat oleh asosiasi perusahaan jasa penilai di Indonesia yang bernama Masyarakat Perusahaan Penilai Indonesia (MAPPI). Namun, kode etik tersebut tidak mempunyai kekuatan hukum yang mengikat sehingga apabila terjadi pelanggaran tanggung jawab yang sesuai dengan kode etik perusahaan jasa penilai hanya akan dikenai sanksi, yang terbesar dikeluarkan dari asosiasi.

\section{PENUTUP}

\section{A. Kesimpulan}

1. Kegiatan-kegiatan perusahaan jasa penilai di Indonesia relatif masih baru dan belum begitu memasyarakat, namun secara hukum eksistensi atau keberadaannya telah diakui sebagai badan usaha yang berbentuk badan hukum.

2. Dalam perlindungan hukum terhadap perbuatan yang melanggar aturan-aturan hukum yang ditanggung oleh sebuah perusahaan jasa penilai kepada pemakai jasa dan pihak ketiga didasarkan atas suatu tanggung jawab perusahaan penilai yang terdapat dalam Kode Etik Penilaian Indonesia (KEPI) dan Pasal 19 Undang Undang Perlindungan Konsumen.

3. Tanggung jawab perusahaan jasa penilai dalam melakukan penilaian aktiva tetap terdapat dalam syarat-syarat pembatasan penilaian yang terdapat dalam laporan hasil penilalan dengan memperhatikan tanggung jawab penilai 
dan kode etik gabungan perusahaan penilai. Selain itu isi perjanjian penilaian aktiva tetap juga menjadi dasar tanggung jawab perusahaan jasa penilai. Segala tindakan dan hasil penilaian perusahaan jasa penilai haruslah dipertanggungjawabkan secara hukum seperti tanggung jawab perdata dan tanggung jawab administrasi. Tanggung jawab perusahaan jasa penilai selama ini masih dituruti oleh perusahaan jasa penilai dalam melakukan penilaian aktiva tetap.

\section{B. Saran}

1. Perlu segera dibentuk dan ditetapkan Undang - Undang Penilaian, sehingga Standar Penilaian Indonesia (SPI) dan Kode Etik Penilai Indonesia (KEPI) yang sudah demikian melelahkan penyusunannya memiliki landasan hukum yang kuat. Mengingat penilai memiliki peran dan fungsi yang cukup penting dalam sistem perekonomian dewasa ini serta belum adanya ketentuan hukum yang secara tegas memberikan sanksi baik pidana maupun perdata.

2. Bersama-sama dengan MAPPI, pemerintah mengembangkan Standarisasi Legalitas Laporan Penilaian yang dilandasi etik profesi penilai.

3. Hendaknya perusahaan jasa penilai dalam melakukan perjanjian-perjanjian penilaian aktiva tetap selalu memperhatikan mutu dan kebenaran dan laporan hasil penilaian dan meningkatkan sumber daya perusahaan agar kualitas dan laporan hasil penilaian semakin baik.

\section{DAFTAR PUSTAKA}

\section{Sumber dari Buku}

Adjie, Habib Adjie. 2008. Status Badan Hukum, Prinsip - Prinsip dan Tanggung Jawab Sosial Perseroan Terbatas. Bandung: Mandar Maju.

Emirzon, Joni. 2000. Aspek-aspek Hukum Perusahaan Jasa Penilai. Jakarta: Gramedia.

Ibrahim, Johanes. 2003. Hukum Bisnis Dalam Persepsi Manusia Modern. Jakarta: Refika Aditama.
KEPI \& SPI: Kode Etik Penilai Indonesia dan Standar Penilaian Indonesia Edisi VI 2015

KEPI \& SPI: Kode Etik Penilai Indonesia dan Standar Penilaian Indonesia Edisi VII 2018

Lalu, Husni Lalu. 2005. Hukum Ketenagakerjaan Indonesia. Jakarta: Raja Grafindo Persada.

Mishkin, Frederic S. The Economic of Money, Banking and Financial Market (Ekonomi Uang, Perbankan, Pasar Keuangan 1) Edisi 8. Jakarta: Salemba Empat.

Muhammad, Abdulkadir. 2006. Hukum Perusahaan Indonesia. Bandung: PT Citra Aditya Bakti..

Prodjodikoro, Wirjono. 1979. Azas-Azas Hukum Perdata Cetakan 7. Bandung: Sumur Bandung.

Prodjodikoro, R. Wirjono. 2000. Asas-asas Hukum Perjanjian. Bandung: Mandar Maju.

Setiawan, R. 1979. Pokok - Pokok Hukum Perikatan. Bandung: Binacipta.

Sidabalok, Janus. 2012. Hukum Perusahaan : Analisis Terhadap Pengaturan Peran Perusahaan dalam Pembangunan Ekonomi Nasional di Indonesia. Bandung: Nuansa Aulia.

Soekanto, Soerjono. 1986. Pengantar Penelitian Hukum. Jakarta: UI Press.

Subekti. 1986. Aneka Perjanjian. Bandung: Alumni.

Sumantoro. 1990. Pengantar Tentang Pasar Modal di Indonesia Cetakan 1, Jakarta: Ghalia Indonesia.

Tantri, Francis. 2009. Pengantar Bisnis. Jakarta: PT RajaGrafindo.

Widoatmodjo, Swawidji. 2004. Jurus Jitu Go Public Cetakan 2. Jakarta: PT. Elex Media Komputindo.

\section{Sumber dari Peraturan Perundang-undangan}

Keputusan Menteri Keuangan Republik Indonesia Nomor 406/KMK.06/2004 tentang Usaha Jasa Penilai Berbentuk Perseroan Terbatas

Kitab Undang - Undang Hukum Perdata (KUHPerdata)

Peraturan Menteri Keuangan Republik Indonesia Nomor /PMK.01/2019 tentang Penilai Publik 
Sumber dari Internet :

https://jdih.kemenkeu.go.id/fullText/2004/406 KMK.06 2004Kep.htm

http://pppk.kemenkeu.go.id/media/document/ 5516/rpmk-revisi-kedua-101---eksposuredraft.pdf

https://www.academia.edu/34665895/Kode Et ik Penilai Indonesia dan Standar Penila ian Indonesia KEPI dan SPI

https://www.ortax.org/ortax/?mod=aturan\&pa ge=show\&id=12436\#aturanleft

http://www.mappi.or.id.

http://www.depkeu.go.id

http://www.appraisalinstitute.org.

\section{Sumber dari yang lain :}

Pusat Pembinaan Akuntansi Dan Jasa Penilai, Sekretaris Jenderal Kementerian Keuangan, Tugas Dan Fungsi Pembinaan Akuntan dan Jasa Penilai. 